One's attitude about two things - the appropriateness of 'grand theory' in the academy, and the possibility of progressive social organizations forming coalitions in real political life - will undoubtedly determine one's receptiveness to this book. Since I am a believer in both, I think this book makes a significant contribution to the field and is a positive sign of things to come from the equality studies discipline.

Faith Armitage

doi:10.1057/palgrave.fr. 9400267

\title{
Laboring women: reproduction and gender in new world slavery
}

Jennifer L. Morgan; University of Pennsylvania Press, Philadelphia, 2004, ISBN 0-8122-1873-6£13.00 (Pbk); ISBN 0-8122-3778-1 £36.00 (Hbk)

Many scholars have emphasized the exploitation of enslaved women in the Americas for both their productive and their reproductive capacities, but none have examined the meaning of childbearing for enslaved women with the sensitivity and subtlety of Jennifer Morgan's Laboring Women. Morgan argues that slaveholders in the early English Atlantic world were acutely conscious of women's reproductive potential, and that this fact had enormous significance for the development of slave societies and for both women's and men's experiences of them. Moving from analysis of early European travellers' sexualized and gendered depictions of African women (a revised version of her much-cited 1997 article in William and Mary Quarterly), through chapters on African gender relations and the slave trade, on slaveowners' gendered strategies in acquiring and using enslaved people's labour, on reproduction from enslaved women's point of view, on agricultural work, and on resistance, Morgan intervenes in a series of crucial debates in the historiography of slavery and the African diaspora.

Laboring Women is full of points that have never previously been made with such clarity. An example is Morgan's discussion of creolization, a phenomenon which, she points out, is inherently linked to reproduction and to family life: the creation of Creole generations depended on African women's child-bearing. Yet in the context of American slave societies, 'creolization was in fact rooted in loss; in the despair of infant death and the altered meanings of women's fertility under the weight of burgeoning plantation regimes'. Morgan's insight should persuade future historians to investigate the familial and gendered substructure of a process often discussed in abstract and andocentric terms. In other places, Morgan articulates points that have been raised elsewhere, but does so in particularly acute and elegant ways. Thus, she emphasizes the difficulties inherent in the concepts of 'resistance' and 'accommodation'. These binary 
categories, she points out, are particularly problematic in discussions of women's reproductive lives precisely because of the tangled complexities of love, violation, and trauma that intersected when women bore children into enslavement. As Morgan notes, for enslaved people reproduction was a site of 'endurance, vulnerability, connection, and pain'. Morgan thus transcends two clichés that have dogged historians' discussions of this issue: on the one hand, the trope of the self-sacrificing, all-loving mother, and on the other, a simplistic interpretation of enslaved women's low fertility rates as straightforward resistance. Throughout the book, Morgan is sensitive to the ultimate unknowability of the past and refuses to resolve the inevitable ambiguity of her sources; indeed, she ends by emphasizing that her project is 'a venture of profound, and profoundly creative, uncertainty'.

In the end, it is Morgan's analysis of the meaning of childbearing and motherhood under slavery - one that bears comparison with Toni Morrison's literary exploration of these themes in Beloved - along with her subtle interpretation of travel writing and political debates, that marks out Laboring Women's significance. This is surprising, because at first sight the heart of the book appears to be a quantitative argument based on Morgan's analysis of thousands of 17 th and 18th century wills and inventories from Barbados and South Carolina. Morgan examines not just the numbers of men, women, and children listed therein, but also the ways in which these individuals were grouped together: as couples, in family groups, and so on. However, although she cites and quotes from these sources repeatedly, the conclusions she draws from them are not particularly surprising, coming down to the fact that slaveowners sought to include at least some women in their slaveholdings; that they understood that they could bequeath as-yet-unborn children to their heirs by leaving them enslaved women; and that the death of an owner was a time of intense vulnerability for enslaved people. Moreover, Morgan presents her demographic evidence in ways that do not always aid understanding. Tables present discrete lists or summaries of individual wills or inventories, demonstrating the number of slaveholdings that included women, children, parents, and so on, but do not give totals to show the proportion of women within slaveholdings, although this figure seems important to Morgan's argument.

One final note: Laboring Women's focus is significantly more narrow than its subtitle, Reproduction and Gender in New World Slavery, suggests. Apart from a few references to the French Caribbean, there is no discussion of non-Anglophone parts of the Americas. Indeed, the book's primary focus is on the North American mainland colonies, and particularly South Carolina. Morgan is interested in Barbados as well, but not primarily for its own sake. Her sample of Barbadian wills ends in 1685, at the point when many Barbadians were leaving to settle the newly established Carolina colony. Barbados thus provides a backdrop and precursor to our understanding of South Carolina, obscuring its continuing history 
into the 18th century and beyond. While a focus on South Carolina is entirely legitimate, the sleight of hand that allows the experience of that part of the world to stand, unmarked, for 'New World slavery' is almost as problematic an obfuscation as is the practice, which Morgan rightly criticizes and brilliantly undoes, of allowing 'slave' to equal 'man'.

Diana Paton

doi:10.1057/palgrave.fr. 9400268

\section{Camp all-American, Hanoi Jane, and the high-and-tight: gender, folklore, and changing military culture}

Carol Burke; Beacon Press, Boston, USA, 2004, ISBN 0-8070-4660-4 (Hbk)

Carol Burke begins her lengthily titled book with the tale of her stint as a cadet at Fort Bragg, the home of the 82nd Airborne Division, the largest parachute force in the world and a sort of mini-army in its own domain, complete with pilots, infantry, artillery, and armour soldiers as well as parachute-trained cooks, mechanics, radiomen, electricians, photojournalists, and computer operators (pp. 2-3). She vividly describes putting on a uniform, rappelling down wooden towers, squeezing into tanks, firing a howitzer, and going along with a squad of cadets ordered to take a bunker at an artillery range - all exercises that were designed to produce the kind of 'warrior leaders' that 'all-American soldiers' are supposed to become. Burke excels where her impeccable eye (and ear) for detail is employed, particularly in her discussions of clothes, speech and ritual, but overall the book is not a conventional ethnography.

Instead, Camp All-American Hanoi Jane, and the High-and-Tight: Gender, Folklore, and Changing Military Culture is a carefully assembled series of approaches to the analysis of the politics of gender in the military and, more precisely, the US Naval Academy. One can read the book just as fruitfully by reading the chapters independently as by reading the book as a whole. Oscillating back and forth from a folklorist's careful descriptions of everyday activities, jokes, marching chants, and initiation rituals to a journalist's sharp investigative accounts of controversies, Burke sheds light on the following issues: the kinds of transformations soldiers undergo during basic training (Chapter 3 ); the making of military masculinities within a strategic framework that declares that men must be made and, at the same time, that insists recruits must be men to begin with (Chapter 4); the enormous difficulties of harmonizing initiation rites that seem to 